\title{
Detection of Infection-Specific Proteins in Viral RNA Replication Complex from Tobacco Plants Infected with Cucumber Mosaic Virus
}

\author{
Naoto NITTA* and Yoichi TAKANAMI**
}

\begin{abstract}
Cucumber mosaic virus (CMV) RNA replication complex was prepared from a crude membrane fraction of infected tobacco leaves and was further purified by a zwitterionic detergent, Zwittergent, and Sepharose 4B column chromatography. The active fraction was found at void volume of the column and in the precipitate after following ultracentrifugation. In vitro products synthesized by the enzyme fraction as well as by the crude enzyme were full-length viral RNAs 1-4, suggesting that the characteristic of the enzyme essentially unchanged by the Zwittergent treatment. Analysis of proteins labeled with radioactivity in CMV-infected tobacco leaf disks showed that the enzyme fraction contained three infection-specific proteins, $\mid \mathrm{Mr} 105,000$, Mr 32,000 and Mr 25,000, which comigrated with viral 1a, 3a and coat proteins, respectively, synthesized in vitro. However, a protein corresponding to 2 a protein encoded by CMV RNA 2 was not identified in in vitro translation system nor in the enzyme fraction. Considering our previous results that inoculation of RNAs 1 and 2 is necessary to induce replicase activity, this result implies that at least 1a protein is closely related to the replicase activity, while the role of 2a protein in RNA replication is yet to be solved.
\end{abstract}

(Received February 23, 1990)

Key words: cucumber mosaic virus, RNA-dependent RNA polymerase, replicase, 1a protein, 2a protein.

\section{INTRODUCTION}

In CMV-infected tobacco leaves or protoplasts, membrane-bound RNA-dependent RNA polymerase (M-RDRP) activity, suggested to be associated with the endoplasmic reticulum ${ }^{18}$, increases prior to virus multiplication ${ }^{11,18}$. The M-RDRP synthesizes in vitro viral positivestranded RNAs 1-4 in the absence of exogenous template RNA, showing that the RDRP activity allows in vitro for the completion of nascent positive-sense chains initiated in vivo ${ }^{11,18}$. This activity is also induced by inoculation with a mixture of viral RNAs 1 and $2^{11)}$. These results indicate that M-RDRP is a CMV RNA replication complex, comprised of at least the translation products of RNA 1 and 2 (1a and 2a proteins), membrane components of the host cell (endoplasmic reticulum) and template viral RNAs.

The major idea addressed in this study is to detect proteins specific for virus infection in the replication complex fraction. For this purpose, we first improved the purification procedures of the replication complex by treatment with a zwitterionic detergent, Zwittergent, followed by Sepharose 4B column chromatography. Subsequently, we radioactively labeled proteins in CMV-infected tobacco leaf disks to analyze in SDS-polyacrylamide gel electrophoresis

* Applied Plant Research Laboratory, Yokohama Center, Japan Tobacco Inc., 6-2, Umegaoka, Midori-ku, Yokohama 227, Japan日本たばこ産業 (侏) 植物開発研究所横浜センター

** Life Science Research Laboratory, Japan Tobacco Inc., 6-2, Umegaoka, Midori-ku, Yokohama 227, Japan日本たばこ産業 (侏) 生命科学研究所 
(SDS-PAGE). Involvement of these viral 1a and $2 \mathrm{a}$ proteins in the replication complex are discussed. A part of this work was presented at the Annual Meeting of the Phytopathological Society of Japan in 1989.

\section{MATERIALS AND METHODS}

Virus and RNAs. CMV (CMV-Y) was propagated in tobacco plants (Nicotiana tabacum cv. Xanthi-nc) grown in an air conditioned greenhouse (22-28 C) and purified as described ${ }^{17}$. Both CMV RNA 1 and RNA 2 were fractionated by $2.5 \%$ agarose gel electrophoresis in TAE buffer containing $40 \mathrm{mM}$ Tris-acetic acid, $\mathrm{pH}$ 8.0, $2 \mathrm{mM}$ EDTA, and recovered by electroelution using NA-45 DEAE membrane (Schleicher \& Schuell). Fractions of RNAs 1+2, RNA 3 and RNA 4 were prepared by sucrose density gradient centrifugation as previously described ${ }^{11}$. These fractionated RNAs were used for in vitro translation experiments.

Preparation of M-RDRP. Tobacco leaves $(20 \mathrm{~g})$ inoculated withi mock or CMV were harvested 3 days after inoculation and homogenized using a mortar and pestle with Buffer A (0.3 M mannitol, $50 \mathrm{mM}$ Tris- $\mathrm{HCl}, \mathrm{pH}$ 8.0, $0.1 \mathrm{M} \mathrm{NH}_{4} \mathrm{Cl}, 1 \mathrm{mM}$ EDTA and $90 \mathrm{mM}$ 2-mercaptoethanol). The homogenate was squeezed through gauze and centrifuged at $1,000 \times g$ for $10 \mathrm{~min}$. The supernatant was centrifuged at $20,000 \times \mathrm{g}$ for $20 \mathrm{~min}$ and the resultant pellet was suspended in Buffer B $\left(20 \mathrm{mM}\right.$ Tris- $\mathrm{HCl}, \mathrm{pH} 8.0,0.1 \mathrm{M} \mathrm{NH}_{4} \mathrm{Cl}, 1 \mathrm{mM}$ EDTA, $0.1 \mathrm{mM}$ DTT and $15 \%$ glycerol) using a glass homogenizer. The homogenate was stirred for more than 1 $\mathrm{hr}$ after adding $1 \%$ Nonidet P-40 (NP-40) and applied onto a Sepharose 4B column $(0.9 \times 27$ $\mathrm{cm})$ previously equilibrated with Buffer B containing $0.1 \%$ NP- 40 . The enzyme was eluted with the equilibrating buffer and fractions (about $0.4 \mathrm{ml}$ ) were collected. The fractions at the void volume of the column were stored frozen. After thawing, the fractions were combined and centrifuged at $100,000 \times g$ for $1.5 \mathrm{hr}$ and the pellet was suspended in Buffer B containing $0.1 \%$ NP-40 using a glass homogenizer. This preparation was termed NP-40 enzyme.

For further purification, Zwittergent (Calbiochem-Behring Corp.) was added to NP-40 enzyme at a concentration of $1 \%$ and stirred for more than $1 \mathrm{hr}$ and then applied onto a Sepharose 4B column as described above except for the addition of $0.1 \%$ Zwittergent to the equilibrating buffer. Fractions were collected and a part of each fraction was used for assay of RDRP activity. All procedures were done on ice or at $4 \mathrm{C}$.

RDRP assay and pulse-chase experiment. The standard assay was as described previously ${ }^{11)}$. The reaction mixture contained $50 \mathrm{mM}$ Tris- $\mathrm{HCl} \mathrm{pH} 8.0,5 \mathrm{mM} \mathrm{MgCl}, 20 \mathrm{mM}$ $\left(\mathrm{NH}_{4}\right)_{2} \mathrm{SO}_{4}, 7.5 \mathrm{mM}$ DTT, $70 \mu \mathrm{g} / \mathrm{ml}$ actinomycin D, $0.023 \mu \mathrm{mol}$ each of ATP, CTP and UTP, $1.7 \mu \mathrm{Ci}$ of $\left[{ }^{3} \mathrm{H}\right]-\mathrm{GTP}$ (10 to $20 \mathrm{Ci} / \mathrm{mmol}$; Amersham) and $10 \mu \mathrm{l}$ of the enzyme. The mixture was incubated for $60 \mathrm{~min}$ at $30 \mathrm{C}$. Of this mixture $30 \mu \mathrm{l}$ were counted on DEAE-cellulose (Whatman DE-81) disks after thorough washing.

Pulse-chase study of in vitro RNA synthesis was carried out using large scale reaction mixtures $(60-90 \mu \mathrm{l})$ containing $\left[{ }^{32} \mathrm{P}\right]-\mathrm{GTP}(300 \mathrm{Ci} / \mathrm{mmol})$ instead of $\left[{ }^{3} \mathrm{H}\right]-\mathrm{GTP}$. After pulses for 10 or $20 \mathrm{~min}$ or labeling for $45 \mathrm{~min}$, reactions were continued with excess amount of cold GTP for a total of $60 \mathrm{~min}$. The RNA in the reaction mixtures was extracted with chloroform $/ \mathrm{phenol}$ and then precipitated by ethanol.

Electrophoresis of $\boldsymbol{R N A}$. [ $\left.{ }^{32} \mathrm{P}\right]-\mathrm{RNA}$ samples were electrophoresed in horizontal $1.5 \%$ agarose gels under denaturing conditions according to the method of McMaster and Carmichael ${ }^{8)}$. Double- and single-stranded CMV RNA were denatured, coelectrophoresed with the samples, and located by staining with acridine orange ${ }^{8)}$. The radioactive bands were detected by autoradiography.

In vitro protein synthesis. The standard system for protein synthesis contained per $10 \mu \mathrm{l}$ final volume: $7 \mu \mathrm{l}$ of rabbit reticulocyte lysate (Amersham, N. 90), $2 \mu \mathrm{l}$ of viral RNA and $1 \mu \mathrm{l}$ of $\mathrm{L}-\left[{ }^{35} \mathrm{~S}\right]$ methionine $(1000 \mathrm{Ci} / \mathrm{mmol}$, Amersham). The final concentration of viral RNA was $20-50 \mathrm{ng} / 10 \mu \mathrm{l}$. Incubation was for $1 \mathrm{hr}$ at $30 \mathrm{C}$. The reactions were stopped by adding 
the sample buffer for SDS-PAGE containing $62.5 \mathrm{mM}$ Tris- $\mathrm{HCl}, \mathrm{pH} 6.8,10 \%$ glycerol, $5 \%$ 2-mercaptoethanol, $2 \%$ SDS and $0.1 \%$ bromophenol blue.

In vivo protein synthesis in tobacco leaf disks infected with CMV. To obtain radioactively labeled proteins from healthy and CMV-infected tobacco leaves, mock- or CMVinfected leaves were harvested 3 days after inoculation, and 16 leaf disks $(1 \mathrm{~cm}$ in diameter) were excised from the leaves. The disks were submerged and infiltrated by vacuum in a medium containing $1 \mathrm{mM}$ Tris- $\mathrm{HCl}, \mathrm{pH} 7.0,20 \mu \mathrm{g} / \mathrm{ml}$ of actinomycin $\mathrm{D}, 100 \mu \mathrm{g} / \mathrm{ml}$ of chloramphenicol, $50 \mu \mathrm{Ci} / \mathrm{ml}$ of $\mathrm{L}_{-}\left[{ }^{35} \mathrm{~S}\right]$ methionine $\left(1,000 \mathrm{Ci} / \mathrm{mmol}\right.$, Amersham) and $46 \mu \mathrm{Ci} / \mathrm{ml}$ of $\left[{ }^{14} \mathrm{C}\right]$ amino acid mixture $(50 \mathrm{mCi} /$ milligramatom of carbon, Amersham) (L-alanine, L-arginine, L-aspartic acid, L-glutamic acid, glycine, L-histidine, L-isoleucine, L-leucine, L-lysine, L-methionine, L-phenylalanine, L-proline, L-serine, L-threonine, L-tyrosine and L-valine). The leaf disks then were incubated in petri dishes under illumination of about 10,000 lux at $35 \mathrm{C}$ for $12 \mathrm{hr}$. After incubation, Zwittergent enzyme fraction was prepared as described above except that Zwittergent was added to the $20,000 \times g$ pellet sample simultaneously with NP-40 and was applied onto a column previously equilibrated with Buffer B containing both detergents at a respective concentration of $0.1 \%$. The void volume fraction of Sepharose $4 \mathrm{~B}$ column chromatography was stored frozen at $-20 \mathrm{C}$ until use for SDS-PAGE.

SDS-PAGE of protein. SDS-gel electrophoresis of proteins on $10 \%$ polyacrylamide gels was done according to Laemmli6). SDS-PAGE standard proteins (Bio-Rad) plus CMV coat protein or $\left[{ }^{14} \mathrm{C}\right]$-methylated proteins (Amersham) were used as marker proteins. The proteins were silver-stained according to Morrissey ${ }^{9}$. Radioactive proteins were detected by autoradiography using X-ray film pre-exposed according to Laskey and Mills ${ }^{7}$.

\section{RESULTS}

\section{Further purification of NP-40 enzyme}

As previously reported, NP-40 enzyme was prepared by Percoll discontinuous densitygradient centrifugation followed by treatment with NP-40 and Sepharose 4B column chromatography ${ }^{18)}$. In this study, we found that density-gradient centrifugation could be omitted. Besides, Zwittergent was found to be by far the most effective among the detergents tested [Zwittergent, CHAPS (Bio-Rad), CHAPSO (Bio-Rad), Lubrol PX (Sigma)] to remove miscellaneous contaminating proteins from the NP-40 enzyme fraction (Data not shown). Therefore, NP-40 enzyme was treated with Zwittergent and chromatographed as described under Materials and Methods. Figure 1 shows the results of Sepharose 4B column chromatography of RDRP activity after Zwittergent treatment. The activity were found at void volume and the active fractions were slightly turbid and completely free from greenish pigments. The

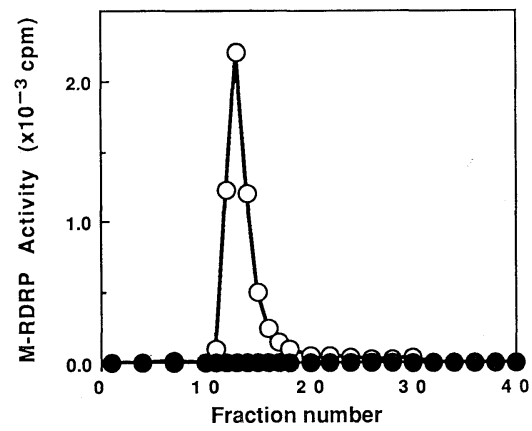

Fig. 1. Elution pattern of M-RDRP activity in Zwittergent enzyme on Sepharose 4B column chromatography. The enzyme was prepared from CMV-infected tobacco leaves (O) or from mock-inoculated leaves (๑). 
activity was recovered in the precipitate after centrifugation at $100,000 \times g$, like NP-40 enzyme, and the fraction was referred to as Zwittergent enzyme.

\section{Analysis of in vitro $R N A$ products synthesized by Zwittergent enzyme}

To examine if the characteristics of Zwittergent enzyme changed by the detergent, pulsechase and time course experiments of in vitro RNA synthesis were carried out. After pulselabeling for 10 or $20 \mathrm{~min}$, polydisperse bands were observed. After pulse and chase for a total of $1 \mathrm{hr}$, the bands were clearly defined and comigrated with viral RNAs 1-4 (Fig. 2). This result indicates that this enzyme also completes the nascent positive-sense chains initiated in vivo as well as the crude M-RDRP enzyme does ${ }^{18)}$.

\section{$S D S-P A G E$ of Zwittergent enzyme fraction}

To identify proteins specific for virus infection in Zwittergent enzyme, the enzyme fractions prepared from mock- and CMV-infected leaves were electrophoresed and silver stained (Fig. 3). There were two protein bands of $\mathrm{Mr} 105,000$ and 24,000, specific for infected leaves, and one band of $\mathrm{Mr} 42,000$ which was much enhanced than in the sample from healthy leaves. The band of $\mathrm{Mr} 24,000$ would have to be $\mathrm{CMV}$ coat protein because it comigrated with the marker coat protein.

\section{In vitro protein synthesis of CMV RNAs by rabbit reticulocyte lysate}

Fractionated viral RNAs were translated in vitro in rabbit reticulocyte lysate in the presence of $\left[{ }^{35} \mathrm{~S}\right]$ methionine and the synthesized proteins were electrophoresed and then autoradiographed (Fig. 4). The largest products of RNAs 1, 3 and 4 were estimated to be about Mr 105,000, Mr 32,000 and Mr 25,000, respectively. The sizes of the translation products were in good agreement with those deduced from the nucleotide sequences of RNA 1 (Mr 111,462) ${ }^{4}$ and 3 (Mr 30,478 and 24,113) ${ }^{10)}$ of the Y strain. In contrast, the largest product of RNA 2, which has slightly lower mobility than the product of RNA 1, was Mr 110,000 and the second largest one was Mr 105,000. The molecular weights of both bands were higher than the Mr 96,720 expected from the nucleotide sequence of RNA 2 of the Y strain ${ }^{5)}$. Moreover, synthesis of the largest one was not reproducible (See Fig. 4, lanes 5,8). These results imply that RNA 2 is not translated correctly in rabbit reticulocyte lysate because of unknown reasons.

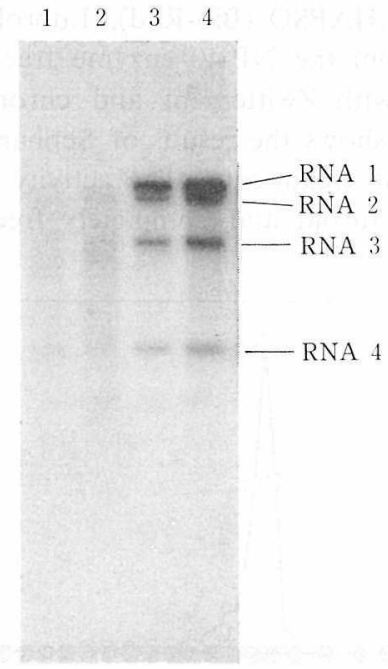

Fig. 2. Pulse-chase experiment of in vitro RNA synthesis by Zwittergent enzyme. Lane 1, pulse for $10 \mathrm{~min}$; lane 2, pulse for $20 \mathrm{~min}$; lane 3, pulse for $20 \mathrm{~min}$ and chase for 40 min; lane 4, incubation for $45 \mathrm{~min}$ and chase for $15 \mathrm{~min}$. All samples including marker CMV RNAs were denatured with glyoxal before electrophoresis. 


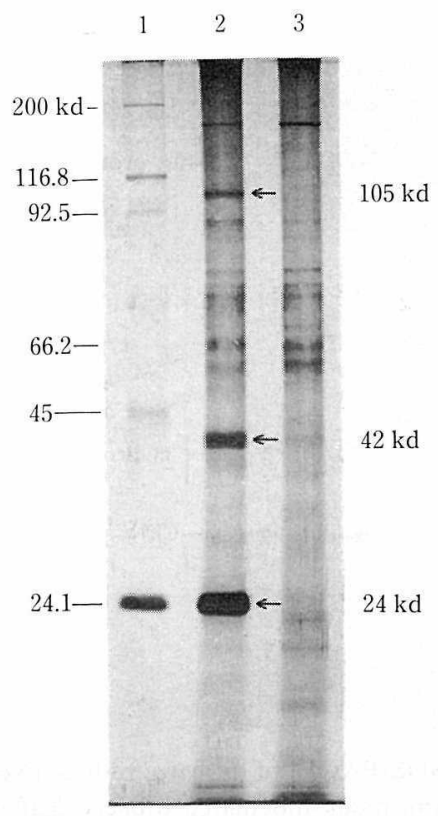

Fig. 3. SDS-PAGE of proteins in Zwittergent enzyme fraction. Lane 1, marker proteins: myosin $(200 \mathrm{kd}), \beta$-galactosidase $(116.3 \mathrm{kd})$, phosphorylase $\mathrm{B}(92.5 \mathrm{kd})$, bovine serum albumin $(66.2 \mathrm{kd})$, ovalbumin $(45 \mathrm{kd})$ and CMV coat protein $(24.1 \mathrm{kd})$; lane 2 , Zwittergent enzyme fraction from CMV-infected tobacco leaves; lane 3, Zwittergent enzyme fraction from mock-inoculated tobacco leaves.

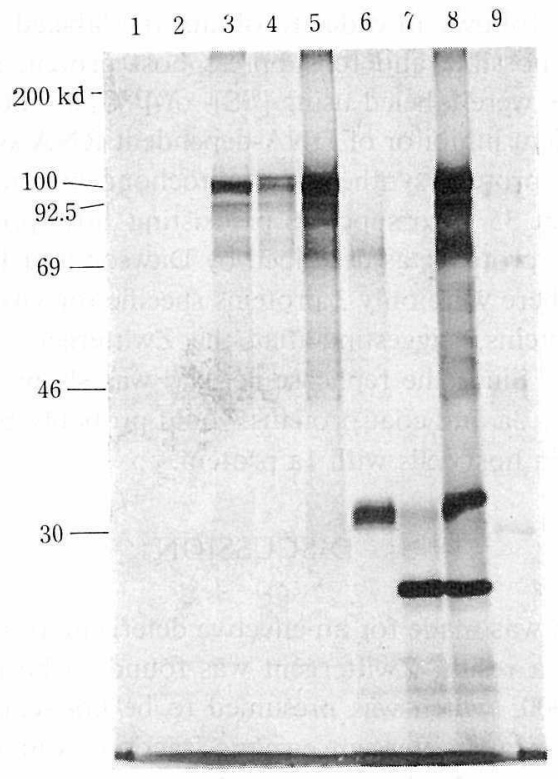

Fig. 4. In vitro protein synthesis of viral RNAs in rabbit reticulocyte lysate. Lane 1 and 9 , $\left[{ }^{14} \mathrm{C}\right]$ methylated marker proteins: myosin $(200 \mathrm{kd})$, phosphorylase B (100 and $\left.92.5 \mathrm{kd}\right)$, bovine serum albumin $(69 \mathrm{kd})$, ovalbumin $(46 \mathrm{kd})$ and carbonic anhydrase $(30 \mathrm{kd})$; lane 2, no RNA; lane 3, CMV RNA 1; lane 4, CMV RNA 2; lane 5, CMV RNAs $1+$ 2; lane 6, CMV RNA 3; lane 7, CMV RNA 4; lane 8, unfractionated CMV RNA. 


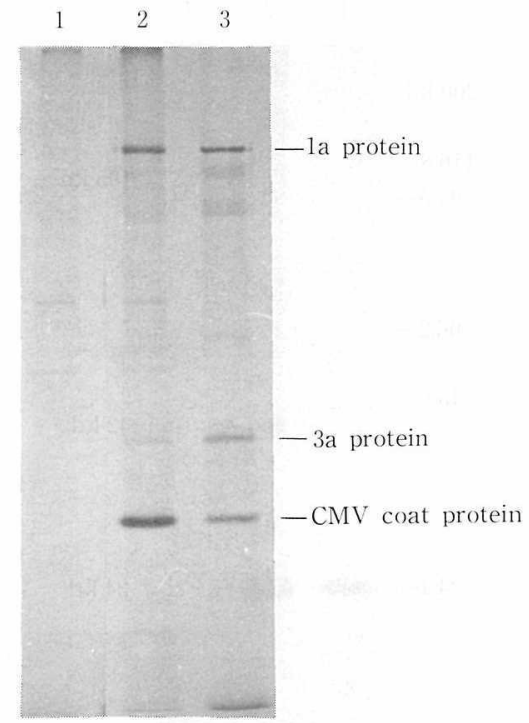

Fig. 5. Autoradiography of SDS-PAGE of in vivo radioactively labeled proteins. Lane 1, Zwittergent fraction from mock-inoculated tobacco leaf disks; lane 2, Zwittergent fraction from CMV-infected tobacco leaf disks; lane 3, in vitro translation products of unfractionated CMV RNA which is the same but diluted sample shown in Fig. 4, lane 8.

\section{In vivo protein synthesis in tobacco leaf disks infected with CMV}

Since nonstructural proteins of CMV have not been detected in vivo yet ${ }^{3,13,14)}$, we designed an experimental system as follows in order to obtain the labeled proteins having higher specific radioactivity as much as possible and to suppress host protein synthesis. Proteins in CMVinfected tobacco leaf disks were labeled using $\left[{ }^{35} \mathrm{~S}\right]-$ or $\left[{ }^{14} \mathrm{C}\right]$-amino acids mixture in the presence of actinomycin D, an efficient inhibitor of DNA-dependent RNA synthesis, and chloramphenicol, which is an inhibitor of protein synthesis in mitochondria and chloroplasts. Furthermore, the disks were incubated at $35 \mathrm{C}$ to suppress preexisting host protein synthesis without inducing synthesis of heat shock proteins, as described by Dawson and Boyd ${ }^{11}$.

Figure 5 shows that there were only 3 proteins specific for virus-infection, which comigrated with 1a, 3a and coat proteins, suggesting that the Zwittergent fraction (replication complex) contains viral 1a protein. Since the replicase activity was shown to be induced by inoculation only with RNAs 1 and $2^{11)}$, $3 a$ and coat proteins would probably be detected due to their sharing sites for protein synthesis in host cells with 1a protein.

\section{DISCUSSION}

In this study, a search was made for an effective detergent to remove contaminating proteins from NP-40 enzyme. As a result, Zwittergent was found to be the most effective.

A protein of $\mathrm{Mr} 42,000$, which was presumed to be host-encoded, was detected as one of the predominant proteins in a Zwittergent enzyme fraction from CMV-infected leaves by SDSPAGE and silver staining (Fig. 3), but was not detected by in vivo radioactive labeling experiment (Fig. 5). The results may suggest that the protein is not synthesized de novo. However, a possibility that the protein could be a host component of the replication complex cannot be excluded.

RNA 2 was not translated in vitro into a protein of the size predicted from the nucleotide 
sequence of Y strain RNA $2^{5}$ (Fig. 4). Similar results have been reported with RNA 2 of the $\mathrm{Q}$ strain, showing that the RNA was translated in vitro into proteins of $\mathrm{Mr} 120,000-110,000^{2,15}$ ) which were larger than the 1a protein translated in vitro and larger than estimated from the nu-

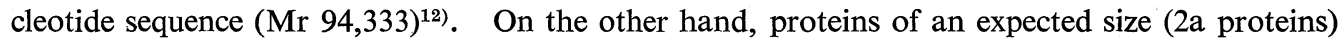
were translated in vitro from RNA $2 \mathrm{~s}$ of brome mosaic and alfalfa mosaic viruses, which also have tripartite genomes like $\mathrm{CMV}^{16,19}$. Although the reason why a protein translated in vitro from CMV RNA 2 does not show the mobility expected from the deduced $\mathrm{Mr}$ in SDS-PAGE is unclear, it might be due to the secondary structure of the protein translated in vitro.

The protein comigrating with the 1a protein translated in vitro was detected in the in vivo labeled proteins. As far as we know, this is the first report to detect a protein in vivo which is suggested to be virus-encoded, non-structural CMV protein. This result implies that the CMV RNA replication complex contains 1a protein. On the other hand, the protein corresponding to $2 \mathrm{a}$ protein was not detected, as shown in Fig. 5, which suggests that 2a protein is not present in the Zwittergent enzyme fraction prepared in this study or was not detectable, if present. Considering the result of our previous study demonstrating that coexisting of CMV RNA 1 and 2 is indispensable to induce replicase activity ${ }^{11)}$, 2 a protein must be involved in some steps of CMV RNA replication. We feel that further experiments and data are necessary to solve the functions of 1a and $2 \mathrm{a}$ proteins in virus RNA replication.

The authors are grateful to Dr. Fujimori and Dr. Tanaka, Applied Plant Research Laboratory, Yokohama Center, Japan Tobacco Inc. for encouragement.

\section{Literature cited}

1. Dawson, W.O. and Boyd, C. (1987). Plant Mol. Biol. 8: 145-149.

2. Gill, D.S., Kumarasamy, R. and Symons, R.H. (1981). Virology 113: 1-8.

3. Gonda, T.J. and Symons, R.H. (1979). J. gen. Virol. 45: 723-736.

4. Kataoka, J., Masuta, C. and Takanami, Y. (1990). Ann. Phytopath. Soc. Japan 56: 501-507.

5. Kataoka, J., Masuta, C. and Takanami, Y. (1990). Ibid. 56: 495-500.

6. Laemmli, U.K. (1970). Nature 227: 680-685.

7. Laskey, R.A. and Mills, A.D. (1975). Eur. J. Biochem. 56: 335-341.

8. McMaster, G.K. and Carmichael, G.G. (1977). Proc. Natl. Acad. Sci. USA 74: 4835-4838.

9. Morrissey, J.H. (1981). Anal. Biochem. 117: 307-310.

10. Nitta, N., Masuta, C., Kuwata, S. and Takanami, Y. (1988). Ann. Phytopath. Soc. Japan 54: 516522.

11. Nitta, N., Takanami, Y., Kuwata, S. and Kubo, S. (1988). J. gen. Virol. 69: 2695-2700.

12. Rezaian, M.A., Williams, R.H.V., Gordon, K.H.J., Gould, A.R. and Symons, R.H. (1984). Eur. J. Biochem. 143: 277-284.

13. Roberts, P.L. and Wood, K.R. (1981). Phytopath. Z. 102: 257-265.

14. Roberts, P.L. and Wood, K.R. (1981). Arch. Virol. 70: 115-122.

15. Schwinghamer, M.W. and Symons, R.H. (1977). Virology 79: 88-108.

16. Shih, D.S. and Kaesberg, P. (1976). J. Mol. Biol. 103: 77-88.

17. Takanami, Y. (1981). Virology 109: 120-126.

18. Takanami, Y., Nitta, N. and Kubo, S. (1989). Ann. Phytopath. Soc. Japan 55: 635-642.

19. Van Tol, R.G.L. and Van Vloten-Doting, L. (1979). Eur. J. Biochem. 93: 461-468.

\section{和 文 摘 要}

新田直人・高浪洋一 : キュウリモザイクウイルス RNA 複製酵素複合体画分からの感染特異的蛋白の検出

キュウリモザイクウイルス (CMV) 感染タバコ葉からウイルス RNA 複製酵素複合体画分を調製し，両性 界面活性剂Zwittergent で処理した後, ゲル濾過によって部分精製した。この部分精製醭素標品 (Zwittergent 酵素) の in vitro 合成産物は, 粗醭素のそれと同様に完全長ウイルス RNA 1 4 であった。CMV 感染タ バコ葉から作製したリーフディスクに放射性アミノ酸を取り込ませて培養した後, Zwittergent 酵素画分を 
調製し電気泳動を行った。その結果，同画分からは感染葉に特異的な 3 種の蛋白が検出され，さらに，それ らは in vitro で合成されたウイルス 1a，3a ならびに外被蛋白と電気泳動的に同一移動度を示した。しかし ながら，RNA 2 にコードされた 2a 蛋白に対応する蛋白は in vitro 翻訳実験に括いては特定できず，また酵 素画分からは検出されなかった。ウイルス RNA 複製酵素活性の誘導には RNA 1 执よび 2 両者の接種が必 要であるといら既報の実験結果を考台合わせると，少なくとも 1a 蛋白は複製酵素活性に密接に関連してい ると考えられるが，2a 蛋白と複製酵素との関係については，さらに検討が必要である。 